\title{
Antifungal Activity of Local Anesthetics Against Candida Species
}

\author{
Cidália Pina-Vaz, 1,2,3* Acácio Gonçalves Rodrigues, ${ }^{1,2}$ \\ Filipe Sansonetty, ${ }^{2}$ J. Martinez-De-Oliveira, ${ }^{4}$ António F. Fonseca, ${ }^{1}$ \\ and Per-Anders Mårdh 5 \\ ${ }^{1}$ Department of Microbiology, Porto School of Medicine, University of Porto, Porto, Portugal \\ ${ }^{2}$ Institute of Pathology and Molecular Immunology of Porto University, Porto, Portugal \\ ${ }^{3}$ Institute of Molecular and Cell Biology, Porto School of Medicine, University of Porto, \\ Porto, Portugal \\ ${ }^{4}$ Department of Gynaecology, Porto School of Medicine, University of Porto, Porto, Portugal \\ ${ }^{5}$ Department of Obstetrics and Gynaecology, Lund University, Lund, Sweden
}

\begin{abstract}
Objective: To evaluate the activity of benzydamine, lidocaine, and bupivacaine, three drugs with local anesthetic activity, against Candida albicans and non-albicans strains and to clarify their mechanism of activity.

Methods: The minimal inhibitory concentration (MIC) was determined for 20 Candida strains (18 clinical isolates and two American Type Culture Collection strains). The fungistatic activity was studied with the fluorescent probe FUN-1 and observation under epifluorescence microscopy and flow cytometry. The fungicidal activity of the three drugs was assayed by viability counts. Membrane alterations induced in the yeast cells were evaluated by staining with propidium iodide, by quantitation of intracellular $\mathrm{K}^{+}$leakage and by transmission electron microscopy of intact yeast cells and prepared spheroplasts.

Results: The MIC ranged from $12.5-50.0 \mu \mathrm{g} / \mathrm{mL}, 5.0-40.0 \mathrm{mg} / \mathrm{mL}$, and $2.5-10.0 \mathrm{mg} / \mathrm{mL}$ for benzydamine, lidocaine, and bupivacaine, respectively. The inhibitory activity of these concentrations could be detected with the fluorescent probe FUN-1 after incubation for 60 minutes. A very fast fungicidal activity was shown by $0.2,50$, and $30 \mathrm{mg} / \mathrm{mL}$ of benzydamine, lidocaine, and bupivacaine, respectively.

Conclusions: At lower concentrations, the tested drugs have a fungistatic activity, due to yeast metabolic impairment, while at higher concentrations they are fungicidal, due to direct damage to the cytoplasmic membrane. Infect. Dis. Obstet. Gynecol. 8:124-137, 2000. @ 2000 Wiley-Liss, Inc.
\end{abstract}

C andida albicans is a common causative agent of mucosal fungal infections, ${ }^{1,2}$ which are difficult to treat and tend to recur. ${ }^{1,3}$ There has been an increasing rate of candidosis, particularly due to a growing number of immunocompromised patients, e.g., due to iatrogenic measures and to persons infected by human immunodeficiency virus. The increasing use of antifungal drugs, both for prophy-

Grant sponsor: Comissão de Fomento da Investigação em Cuidados de Saúde -Ministério da Saúde; grant number: 113/96. Grant sponsor: Praxis XXI: [Fundação para a Ciência e Tecnologia, Lisboa, Portugal]; grant number: PSAU/C/SAU/ $0014 / 96$.

*Correspondence to: Gidália Pina-Vaz, Department of Microbiology, Porto School of Medicine, 4200 Porto, Portugal. E-mail: micfam@ip.pt 
TABLE I. MICs and $\mathrm{LC}_{50}$ s for benzydamine, lidocaine, bupivacaine, and fluconazole of Candida strains ${ }^{\mathrm{a}}$

\begin{tabular}{|c|c|c|c|c|c|c|c|c|}
\hline Strains & Isolates & $\begin{array}{c}\text { MIC Benz. } \\
(\mu \mathrm{g} / \mathrm{mL})\end{array}$ & $\begin{array}{c}\mathrm{LC}_{50} \text { Benz. } \\
(\mu \mathrm{g} / \mathrm{mL})\end{array}$ & $\begin{array}{l}\text { MIC Lid. } \\
(\mathrm{mg} / \mathrm{mL})\end{array}$ & $\begin{array}{l}\mathrm{LC}_{50} \text { Lid. } \\
(\mathrm{mg} / \mathrm{mL})\end{array}$ & $\begin{array}{l}\text { MIC Bup. } \\
\text { (mg/mL) }\end{array}$ & $\begin{array}{c}\mathrm{LC}_{50} \text { Bup. } \\
(\mathrm{mg} / \mathrm{mL})\end{array}$ & $\begin{array}{l}\text { MIC Flu. } \\
(\mu \mathrm{g} / \mathrm{mL})\end{array}$ \\
\hline C. albicans M36 & Vaginal & 12.50 & - & 5.0 & - & 2.50 & - & $>64$ \\
\hline C. albicans $\mathrm{H} 33$ & Vaginal & 6.25 & - & 5.0 & - & 2.50 & - & I \\
\hline C. albicans SCO & Vaginal & 6.25 & - & 2.5 & - & 1.25 & - & 1 \\
\hline C. albicans M9 & Vaginal & 6.25 & - & 2.5 & - & 1.25 & - & 1 \\
\hline C. albicans Ser 5 & Vaginal & 12.50 & - & 5.0 & - & 2.50 & - & 16 \\
\hline C. albicans $\mathrm{H} 65$ & Vaginal & 12.50 & - & 2.5 & - & 1.25 & - & $>64$ \\
\hline C. albicans $M 28$ & Vaginal & 25.00 & - & 2.5 & - & 1.25 & - & 2 \\
\hline C. albicans H38 & Vaginal & 12.50 & - & 5.0 & - & 2.50 & - & 1 \\
\hline C. albicans 10231 & ATCC & 12.50 & 36.38 & 5.0 & 19.96 & 2.50 & 20.06 & 1 \\
\hline C. albicans H37 & Bronchial wash & 12.50 & 49.14 & 10.0 & 32.11 & 5.00 & 3.621 & $>64$ \\
\hline C. glabrata $\mathrm{H} 30$ & Vaginal & 25.00 & 54.59 & 40.0 & 354.07 & 10.00 & 263.83 & $>64$ \\
\hline C. glabrata $\mathrm{HI} 6$ & Vaginal & 50.00 & 87.59 & 10.0 & 49.45 & 5.00 & 39.56 & 64 \\
\hline C. krusei H9 & Blood & 25.00 & 58.70 & 10.0 & 22.14 & 2.50 & 15.12 & $>64$ \\
\hline C. krusei H32 & Blood & 25.00 & 54.38 & 10.0 & 20.73 & 2.50 & 12.72 & $>64$ \\
\hline C. tropicalis $\mid 3803$ & ATCC & 12.50 & 48.21 & 10.0 & 61.23 & 2.50 & 25.30 & 4 \\
\hline C. tropicalis $\mathrm{HI}$ & Blood & 25.00 & 67.73 & 5.0 & 46.63 & 2.50 & 16.59 & 4 \\
\hline C. guilliermondi MAT 24 & Vaginal & 12.50 & 40.31 & 10.0 & 51.62 & 2.50 & 28.61 & 4 \\
\hline C. guilliermondi MAT 23 & Vaginal & 25.00 & 58.29 & 10.0 & 54.40 & 5.00 & 31.68 & 2 \\
\hline C. lusitaniae $\mathrm{H} 22$ & Vaginal & 25.00 & 74.42 & 10.0 & 54.40 & 5.00 & 102.15 & I \\
\hline C. lusitaniae H54 & Bronchial wash & 50.00 & 88.23 & 5.0 & 27.93 & 2.50 & 16.88 & I \\
\hline
\end{tabular}

aBenzydamine, Benz.; lidocaine, Lid.; bupivacaine, Bup.; fluconazole, Flu.

lactic and therapeutic purposes, has led to the emergence of resistant strains. ${ }^{4,5}$ This situation calls for the search for alternative antifungal drugs.

Many nonantibiotic drugs including antidiuretic, antidiabetic, $\beta$-blockers, psychotherapeutic, and nonsteroidal anti-inflammatory molecules possess an antimicrobial action, which has generally been regarded as a side effect ${ }^{6}$ and therefore neglected for potential clinical use. Benzydamine, lidocaine, and bupivacaine are known nonantibiotic antimicrobials. Topical use of these anesthetic drugs may be useful in the management of cutaneous and vaginal candidosis. We studied the activity and mechanism of action of benzydamine, lidocaine, and bupivacaine against $C$. albicans and non-albicans strains.

\section{MATERIALS AND METHODS Candida Strains}

Twenty Candida strains were used: 18 clinical isolates and two American Type Culture Collection (ATCC) strains ('Table 1). The yeasts were kept at $-70^{\circ} \mathrm{C}$ in Brain-Heart broth (Difco Laboratories, Detroit, MI) with 5\% glycerol until tested. For each experiment, the strains were subcultured twice on Sabouraud agar (Difco) for 24 hours at $35^{\circ} \mathrm{C}$ and either resuspended in saline (stationary growth phase cells) or subcultured in Sabouraud broth to the middle of the exponential growth phase.

\section{Antifungal Drugs}

Benzydamine was obtained from Lepori Angelini (Rome, Italy). Lidocaine and bupivacaine were purchased from Sigma (St. Louis, MO).

\section{Incubation of Yeast Cells With Drugs}

Yeast cells in stationary phase were resuspended in $10 \mathrm{mmol} / \mathrm{L}$ sodium $\mathrm{N}$-2-hydroxyethylpiperazineN-2-ethanesulfonic buffer (HEPES, pH 7.2), supplemented with $2 \%$ glucose ( $\mathrm{GH}$ solution), at a density of $1 \times 10^{6}-5 \times 10^{6}$ cells $/ \mathrm{mL}$, with or without serial concentrations of the drugs (see legends to figures). Incubations were carried out at $35^{\circ} \mathrm{C}$, with shaking at 200 strokes/min. At the end of the incubation, the cells were centrifuged for 10 minutes at $1800 \mathrm{~g}$, and the antifungal activity of the drugs was assayed by viability counts and by staining with the fluorescent probes Propidium Iodide (PI) and FUN-1, as described below.

\section{Determination of Minimal Inhibitory Concentrations}

The minimal inhibitory concentrations (MICs) of the antifungals were determined by a macrodilution test, according to the reference method 
(M27-A protocol) of the National Committee for Clinical Laboratory Standards. ${ }^{7}$

\section{Yeast Cell Counts}

The total number of yeasts in the suspensions was determined in a Neubauer hemocytometer (Agar Scientific Ltd, Stansted, UK). Enumeration of viable yeast cells in the untreated control suspensions and in those exposed to local anesthetics or sodium azide was carried out by counting colonyforming units (CFU) after plating serial dilutions (in saline) of the suspensions on Sabouraud agar plates. The number of colonies was counted after 48 hours of incubation at $35^{\circ} \mathrm{C}$.

\section{Studies of Membrane Damaging}

Two independent procedures were used to assess the capacity of benzydamine, lidocaine, and bupivacaine to damage the fungal cytoplasmic membrane. One relied on the use of the membraneimpermeable fluorescent dye PI. Previous experiments have been carried out to optimize the flow cytometric conditions that were used in the current study (Pina-Vaz et al, in press). That is, optimal results were obtained when using $10^{6}$ yeast cells $/ \mathrm{mL}$, stained with $1 \mu \mathrm{g} / \mathrm{mL}$ of PI, for $30 \mathrm{~min}$ utes in $0.05 \mathrm{~mol} / \mathrm{L}$ sodium HEPES buffer, $\mathrm{pH} 7.2$, at room temperature in the dark. Incubation with $1 \mu \mathrm{g} / \mathrm{mL}$ of PI under the above-mentioned conditions had no toxicity to Candida cells (as determined by viability counts) and stained $100 \%$ of Candida cells killed by boiling for 30 minutes (Pina-Vaz et al., in press). For each sample, the percentage of PI-positive cells was determined by flow cytometry as described in detail below. From these values, the concentration of the assayed drugs resulting in 50\% PI-positive cells was calculated according to a linear regression equation. The PI staining was found to be an adequate indicator of cell death (see "Results"). Therefore, we considered those drug concentrations causing half of the cells to be stained as representing median lethal concentration $\left(\mathrm{LC}_{50}\right)$.

The second method we used to study cytoplasmic membrane damage estimated the leakage of intracellular $\mathrm{K}^{+}$from the yeast cells. Because the intracellular accumulation of $\mathrm{K}^{+}$is higher in yeasts in the exponential growth phase, ${ }^{8}$ Candida cells grown at $35^{\circ} \mathrm{C}$ in Sabouraud broth supplemented with $0.5 \% \mathrm{~K}_{2} \mathrm{HPO}_{4}$ were harvested at the middle of the exponential growth phase. The yeasts were washed twice with saline and exposed at $35^{\circ} \mathrm{C}$ for 10 minutes to the assayed drugs dissolved in saline at indicated concentrations. After 5 and 10 minutes, treated and control suspensions were filtered through $0.45 \mu \mathrm{m}$ Millipore filters (Millipore, MA). The filtrates were assayed for $\mathrm{K}^{+}$using a $\mathrm{K}^{+}$sensitive glass electrode connected to a Spotlyte analyzer (Menarini Diagnostics). The values are presented as the percentage of $\mathrm{K}^{+}$leaked in comparison to that from cells boiled for 30 minutes. ${ }^{9,10}$ Viability counts and the percentage of cells stained by PI were also determined in the suspensions used for the $\mathrm{K}^{+}$leakage assays. The leakage of $\mathrm{K}^{+}$ was also analyzed for Candida cells treated with 20 $\mathrm{mM}$ sodium azide, or with $2 \mu \mathrm{g} / \mathrm{mL}$ of amphotericin $\mathrm{B}$, for 10 minutes.

\section{Assays of Metabolic Vitality}

The processing of the fluorescent probe FUN-1 by the yeast cells was used to detect nonlethal metabolic alterations. Two methods to assess FUN-1
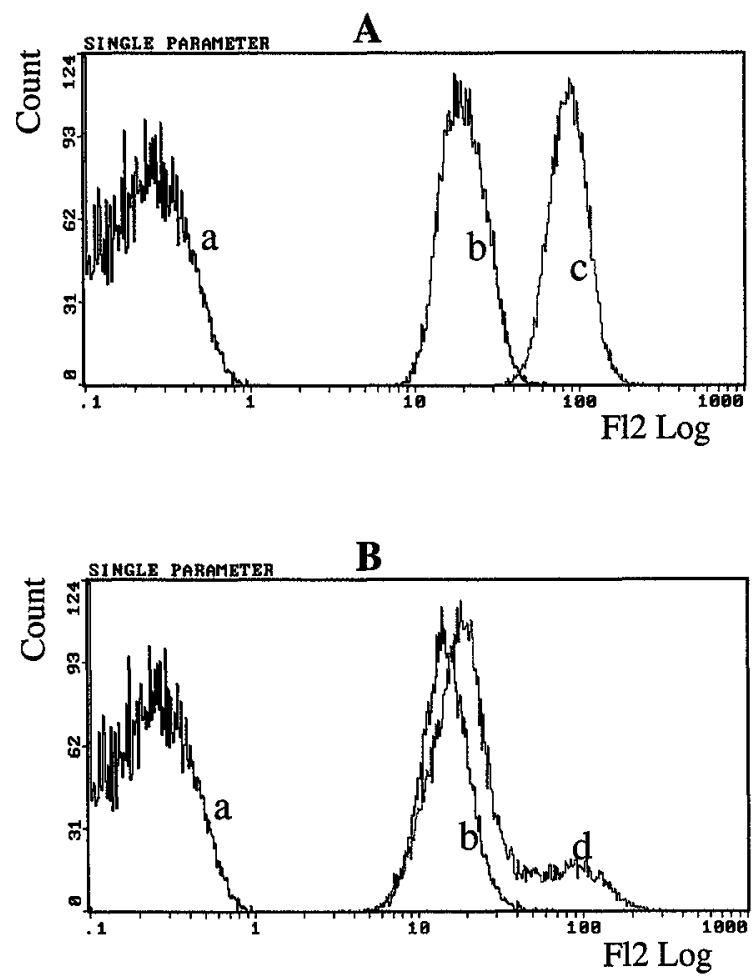

Fig. I. Single parameter histograms of FUN-I stained $C$ albicans, ATCC strain 1023 I cells after I hour of incubation with benzydamine (A) or bupivacaine (B). a: autofluorescence (without FUN-I); b: untreated control; c: treatment with $12.5 \mu \mathrm{g} / \mathrm{mL}$ of benzydamine; d: treatment with 2.5 $\mathrm{mg} / \mathrm{mL}$ of bupivacaine. 
A

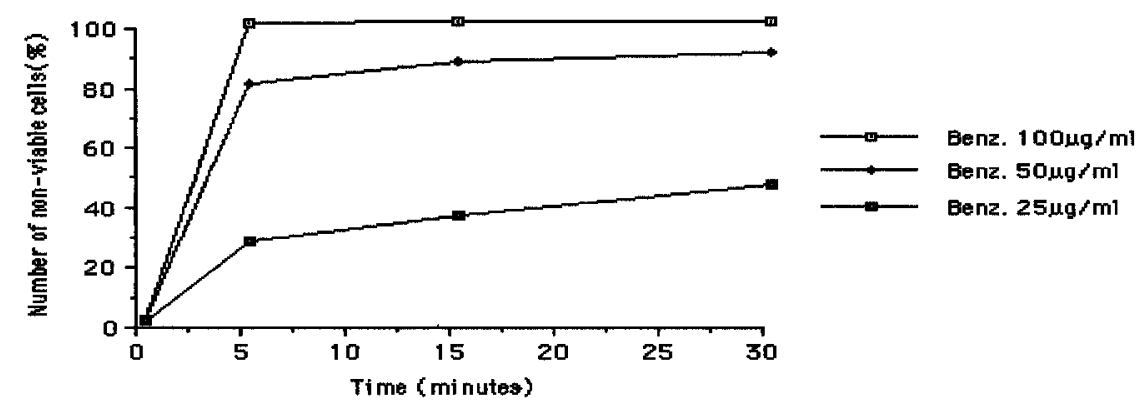

B

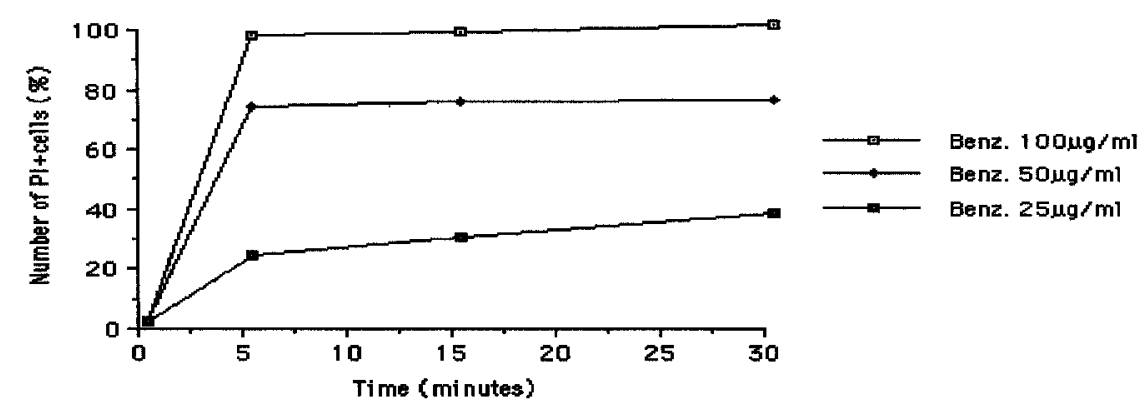

$\mathrm{C}$

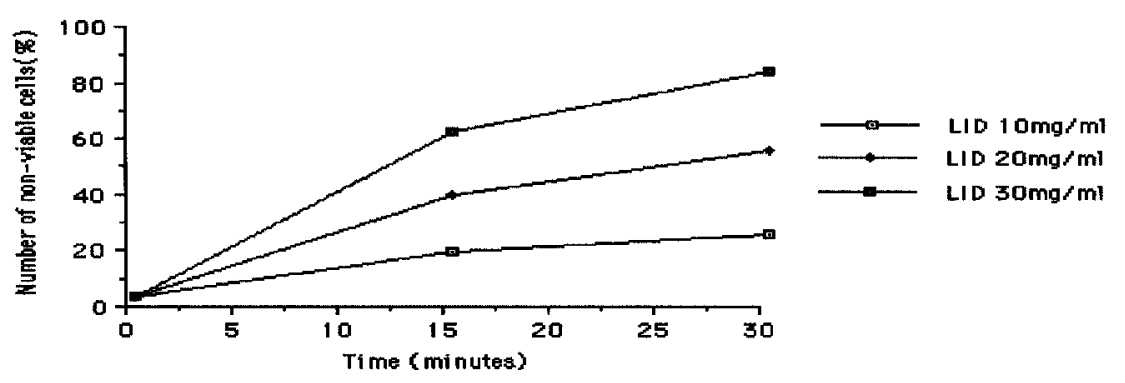

Fig. 2. Percentage of unviable (A, C, E) and Pl-positive, (B, D, F) C. albicans, ATCC strain 1023 I cells exposed for $30 \mathrm{~min}$ to increasing concentrations of benzydamine (benz) (A, B), lidocaine (LID) (C, D) or bupivacaine (BUP) (E, F).

processing were used. Biochemically active cells, stained with this fluorescent membrane-permeable dye, exhibit under fluorescence microscopy orange/red cylindrical intravacuolar structures (CIVS), while nonviable cells or viable cells with severely impaired metabolism do not show these structures. ${ }^{11}$ Metabolically impaired yeast cells show an increased intracellular accumulation of the probe, which can be detected by flow cytometry. ${ }^{12}$ Untreated and treated yeast suspensions in GH so- lution were incubated with $0.5 \mu \mathrm{M}$ of FUN-1 (Molecular Probes Europe BV, Leiden, Netherlands) for 30 minutes at $30^{\circ} \mathrm{C}$ in the dark. To evaluate CIVS formation, the FUN-1 stained cells were mounted on microscope glass slides with the antifading Vectashield Mounting Medium (Vector Laboratories, Burlingane, CA). The percentage of yeasts with CIVS was determined by observing 200 cells under epifluorescence microscopy in a Leitz Laborlux K (Leica, Buffalo, NY) microscope fitted 
D

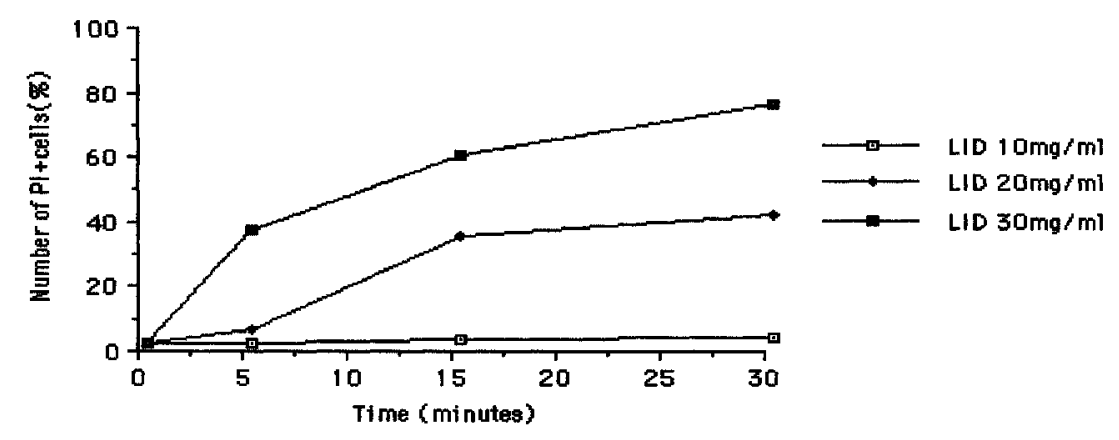

E

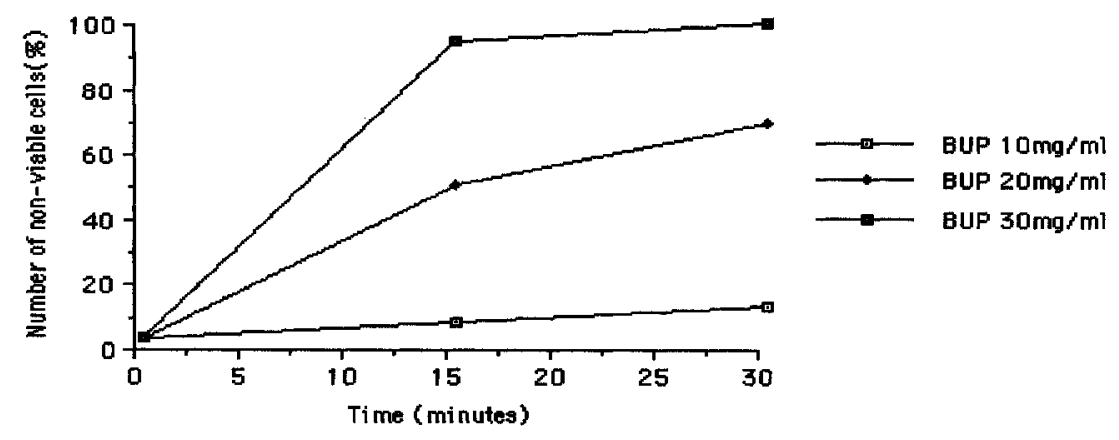

F

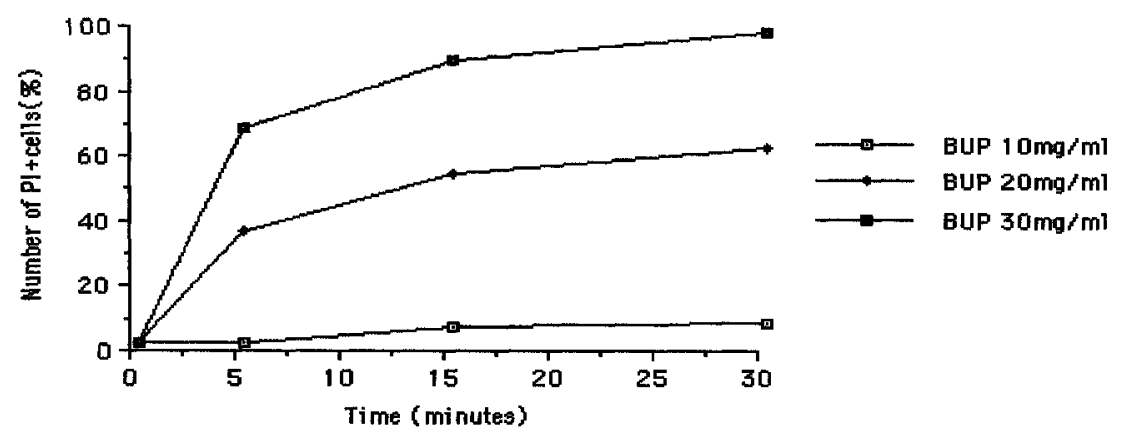

Fig. 2. Continued.

with a mercury 50-W lamp, a BP 450-490-nm excitation filter and a LP 515-nm emission filter. To quantify the intracellular concentration of FUN-1, flow cytometry was used as described below.

\section{Flow Cytometry}

The suspensions were analyzed at $620 \mathrm{~nm}$ (FL3) for PI and at $575 \mathrm{~nm}$ (FL2) for FUN-1, in a Beckman Coulter XL-MCL (Hialeah, FL) flow cytometer, equipped with a $15-\mathrm{mV}$ argon laser with and without the fluorochrome (autofluorescence, as a control).

\section{Spheroplast Formation}

Spheroplasts of $C$. albicans, ATCG strain 10231, were obtained by enzymatic digestion of the cell wall with Lyticase (Boehringer Mannheim, Cat. No 1372464, Mannheim, Germany). ${ }^{13}$ Incubation was made at $35^{\circ} \mathrm{C}$ in YEPD medium ( $1 \%$ yeast extract, $2 \%$ bacto peptone, and $2 \%$ glucose), containing 
A
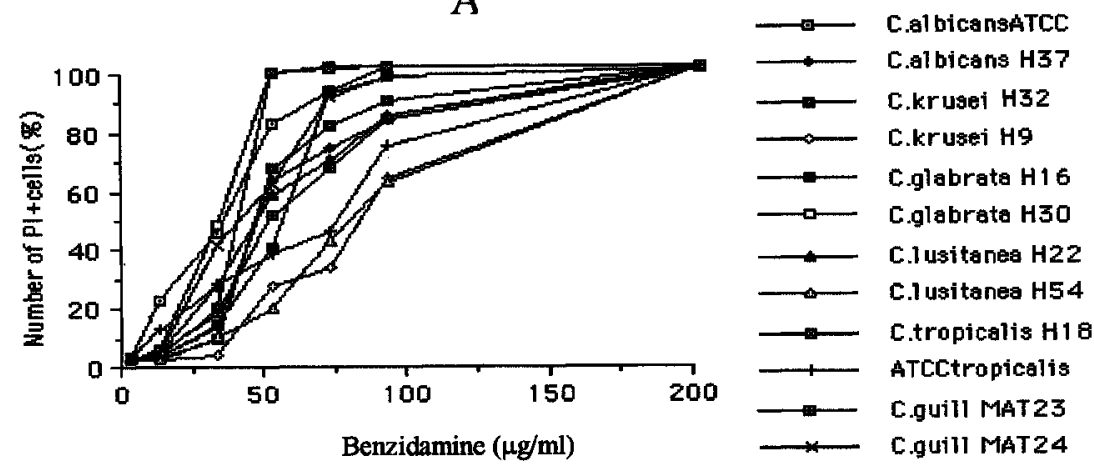

B
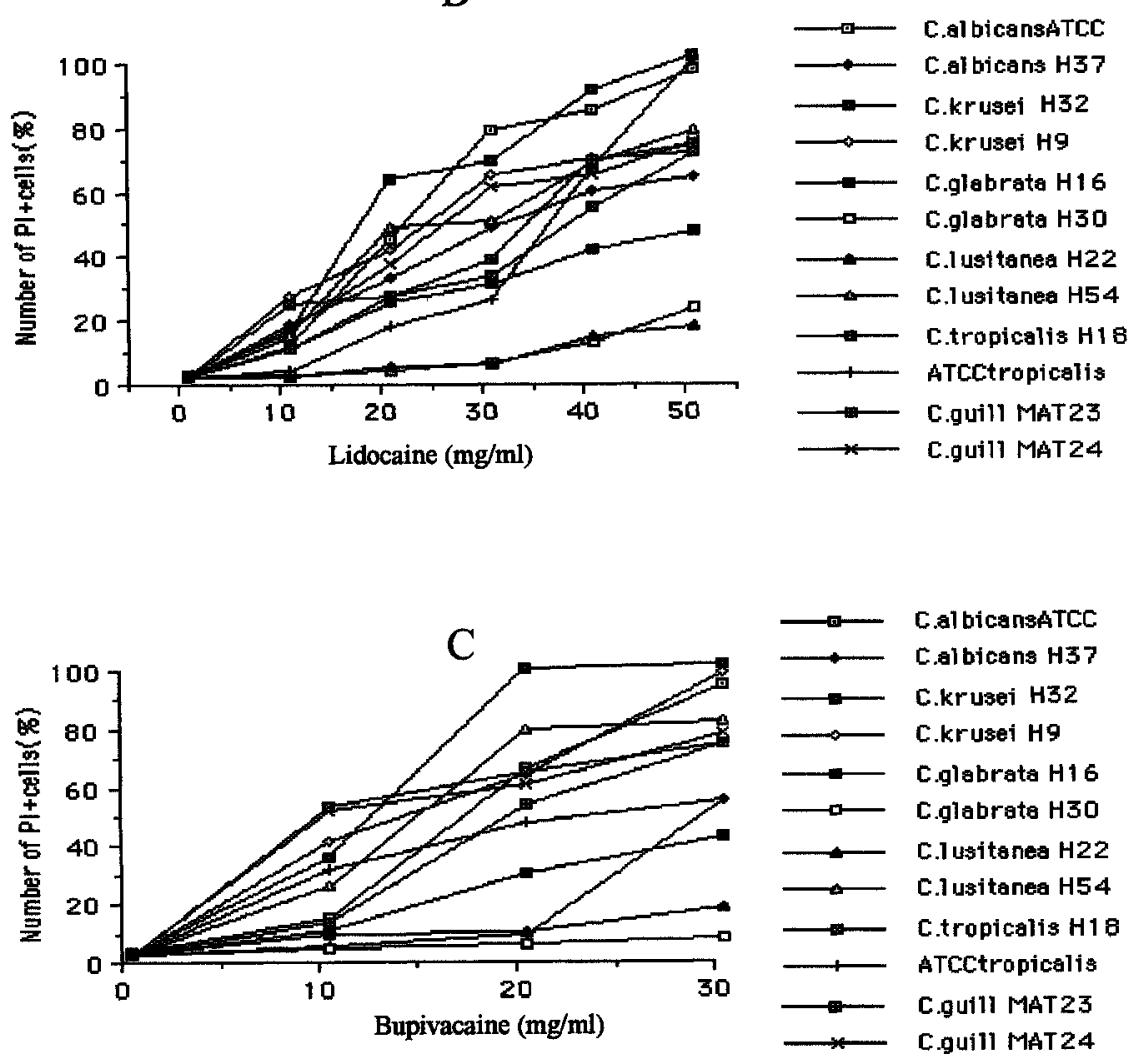

Fig. 3. Percentage of Pl-positive cells in suspensions of Candida strains exposed for 60 min to different concentrations of benzydamine $(\mathbf{A})$, lidocaine $(\mathbf{B})$, or bupivacaine $(\mathbf{C})$.

yeast cells grown to middle of exponential phase (about $1 \times 10^{7}$ cells $/ \mathrm{mL}$ ). The cells were collected by centrifugation at $1800 \mathrm{~g}$ for $10 \mathrm{~min}$, washed once with water and once with $1.4 \mathrm{~mol} / \mathrm{L}$ sorbitol before the pellets were resuspended at a concentration of $1 \times 10^{7}-5 \times 10^{7}$ cells $/ \mathrm{mL}$ in 0.04 M HEPES buffer (pH 7.4), $0.5 \mathrm{M} \mathrm{MgCl}_{2}$, and $0.5 \%$ mercaptoethanol (Sigma) in $1.4 \mathrm{M}$ sorbitol. Lyticase was added at a concentration of 10 units $/ 10^{7}$ cells, and the suspension was incubated at $30^{\circ} \mathrm{C}$ with gentle, occasional shaking. Spheroplast production was monitored by phase contrast microscopy, assessing the lysis of yeast cells exposed to $5 \%$ sodium dodecyl sulfate (SDS). Yeasts unexposed to Lyticase did not lyse with SDS. When most Candida cells were converted into spheroplasts, the suspension was cen- 

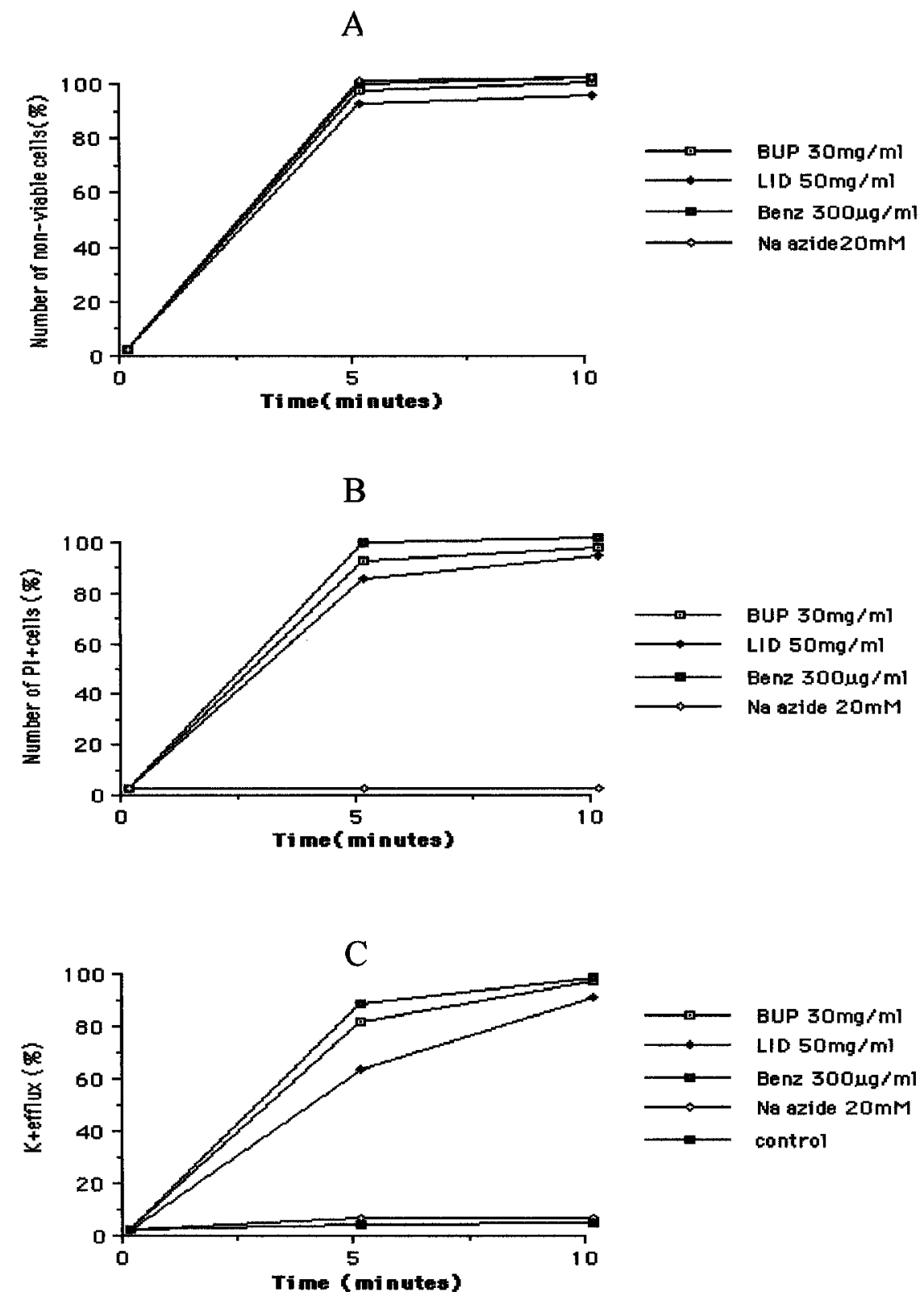

Fig. 4. Exponential phase C. albicans, ATCC strain 1023 I cells exposed for $10 \mathrm{~min}$ to $0.3 \mathrm{mg} / \mathrm{mL}$ of benzydamine (Benz), 50 $\mathrm{mg} / \mathrm{mL}$ of lidocaine (LID), $30 \mathrm{mg} / \mathrm{mL}$ of bupivacaine (BUP) or $20 \mathrm{mM}$ sodium azide ( $\mathrm{Na}$ azide). In the same suspensions, three parameters were determined, i.e., the percentage of nonviable cells (determined by CFU counts) (A), the percentage of Pl-positive cells (B), and $\mathrm{K}^{+}$efflux (as percent of the total intracellular $\mathrm{K}^{+}$) (C).

trifuged at $1800 \mathrm{~g}$ for 10 minutes and the pellet resuspended in GH medium supplemented with 1.4 $\mathrm{M}$ sorbitol with indicated concentrations of the assayed antifungal drugs.

\section{Transmission Electron Microscopy}

To analyze the ultrastructural alterations induced by the tested drugs, $C$. albicans blastoconidia and spheroplasts were studied. Blastoconidia of untreated and treated cells of $C$. albicans strain ATCG 10231, were prefixed with $2.5 \%$ glutaraldehyde in $0.1 \mathrm{M}$ cacodylate buffer, $\mathrm{pH} 7.2$, followed by washing in the same buffer. The cells were then fixed with $1.5 \%$ potassium permanganate in water for 1 hour, ${ }^{14}$ followed by washing with water and postfixation with aqueous $1 \%$ uranyl acetate for 30 
minutes. ${ }^{15}$ Samples of control and treated spheroplasts were prefixed with $2.5 \%$ glutaraldehyde (1 volume of $25 \%$ glutaraldehyde stock solution added to 9 volumes of spheroplast suspensions). After at least 4 hours at room temperature, the samples were washed with $0.1 \mathrm{M}$ cacodylate buffer, $\mathrm{pH} \mathrm{7.2,} \mathrm{and} \mathrm{fixed} \mathrm{overnight} \mathrm{at} \mathrm{room} \mathrm{temperature}$ with $1 \% \mathrm{OsO}_{4}$ in $0.1 \mathrm{M}$ acetate-veronal buffer, $\mathrm{pH}$ 7.0 , supplemented with $10 \mathrm{mM}$ calcium chloride. ${ }^{16}$ After washing with water, the cells were postfixed with aqueous $1 \%$ uranyl acetate for 30 minutes at room temperature. ${ }^{15}$ Fixed intact cells and spheroplasts were dehydrated in ethanol and embedded in Epon (TAAB Aldermaston, Berks, UK). ${ }^{17}$ Ultrathin sections were cut with an LKB Ultratome III microtome (LKB-Produkter AB, Stockolm-Bromma, Sweden) and contrasted with uranyl acetate followed by lead citrate. ${ }^{16}$ To improve visualization of ribosomes in the spheroplasts, sections were treated with $3 \%$ hydrogen peroxide for 10 minutes before lead citrate staining. ${ }^{17}$ Observations and micrographs were done with a Zeiss EM $10 \mathrm{C}$ electron microscope (Carl Zeiss, Oberkochen, Germany).

\section{Statistical Analysis}

Correlation coefficients ( $r$ ) were calculated using the Anova program (program Statistica for Windows, Stat Soft, CA).

\section{RESULTS}

The three drugs tested inhibited growth of all Candida strains studied, with MICs ranging from 6.25 to $50.0 \mu \mathrm{g} / \mathrm{mL}$ for benzydamine, from 1.25 to 40.0 $\mathrm{mg} / \mathrm{mL}$ for lidocaine, and from 2.5 to $10 \mathrm{mg} / \mathrm{mL}$ for bupivacaine (Table 1 ). The correlation coefficients between the MIC of each drug for the 20 strains studied were good when comparing lidocaine with bupivacaine $(r=0.905)$, but not for benzydamine vs. lidocaine $(r=0.212)$ and not for benzydamine vs. bupivacaine $(\mathrm{r}=0.328)$. Short exposure of $G$. albicans strain ATCC 10231 to the MIC of each of the three drugs did not result in any cell death and did not make the cells permeable to PI or induce any significant $\mathrm{K}^{+}$leakage (not shown). However, under these conditions, the drugs significantly impaired the vitality of the Candida cells, as was shown by FUN-1 experiments. Thus, yeast cells exposed for 1 hour to the drugs at the MIC did not form CIVS (not shown), while an increase in the intracellular fluorescence was detected by flow cytometry (Fig. 1).
Treatment of $G$. albicans, ATCC strain 10231, with increasing concentrations of the anesthetics resulted in a dose-dependent fungicidal effect (Fig. 2A, G, and E). Staining with PI showed that the number of PI-positive cells correlated well with the number of nonviable cells (Fig. 2B, D and F). Figure 3 (A, B, and C) shows the effect of a 60 minute exposure of some of the Candida strains investigated to increasing concentrations of the drugs. The drug concentrations resulting in $\mathrm{LC}_{50}$ were calculated for each strain (Table 1). The correlation coefficient between the $\mathrm{LC}_{50}$ of each drug for the 12 strains tested was $r=0.073$ when comparing benzydamine with lidocaine, $r=0.001$ for benzydamine vs. bupivacaine, and $r=0.955$ for lidocaine vs. bupivacaine.

The concentrations of the three drugs causing an extensive rate of killing (Fig. 4A) and permeability to PI (Fig. 4B) in C. albicans, ATCC 10231, cells induced a quick and extensive leakage of intracellular $\mathrm{K}^{+}$(Fig. 4C). A similar pattern of $\mathrm{K}^{+}$ leakage was seen with the membrane-active antifungal amphotericin $\mathrm{B}$, with $85.7 \%$ and $94.1 \%$ of intracellular $\mathrm{K}^{+}$being lost after treatment of $C$. albicans ATCC 10231 cells with $2 \mu \mathrm{g} / \mathrm{mL}$ of the antibiotic for 5 and 10 minutes, respectively. Treatment of $G$. albicans, ATCC strain 10231 cells, with $20 \mathrm{mM}$ sodium azide for 10 minutes resulted in extensive cell death (Fig. 4A) but did not make the cells permeable to PI (Fig. 4B), nor did it induce a significant $\mathrm{K}^{+}$leakage (Fig. 4C). Candida glabrata strain $\mathrm{H} 30$ was the strain most resistant to the three drugs assayed. When it was treated with high concentrations of lidocaine, no $\mathrm{K}^{+}$leakage was seen (not shown).

Transmission electron microscopy showed that exposure of $C$. albicans, ATCC strain 10231, to cidal concentrations of the anesthetics induced severe alterations of the cytoplasmic organelles (Fig. 5).

Exposure of blastoconidia of $C$. albicans, ATCG strain 10231, to Lyticase-under the described conditions-resulted in detergent-sensitive spheroplasts, which often had loose cell wall remnants (Fig. 6A). Only occasionally completely wall-free protoplasts were found. Spheroplasts not exposed to the drugs were intact and showed numerous ribosomes and normal intracellular organelles, i.e., the nucleus and the mitochondria (Fig. 6, A and B) and intact cell membranes with a continuous triplelayered profile (Fig. 7A). On the contrary, when 

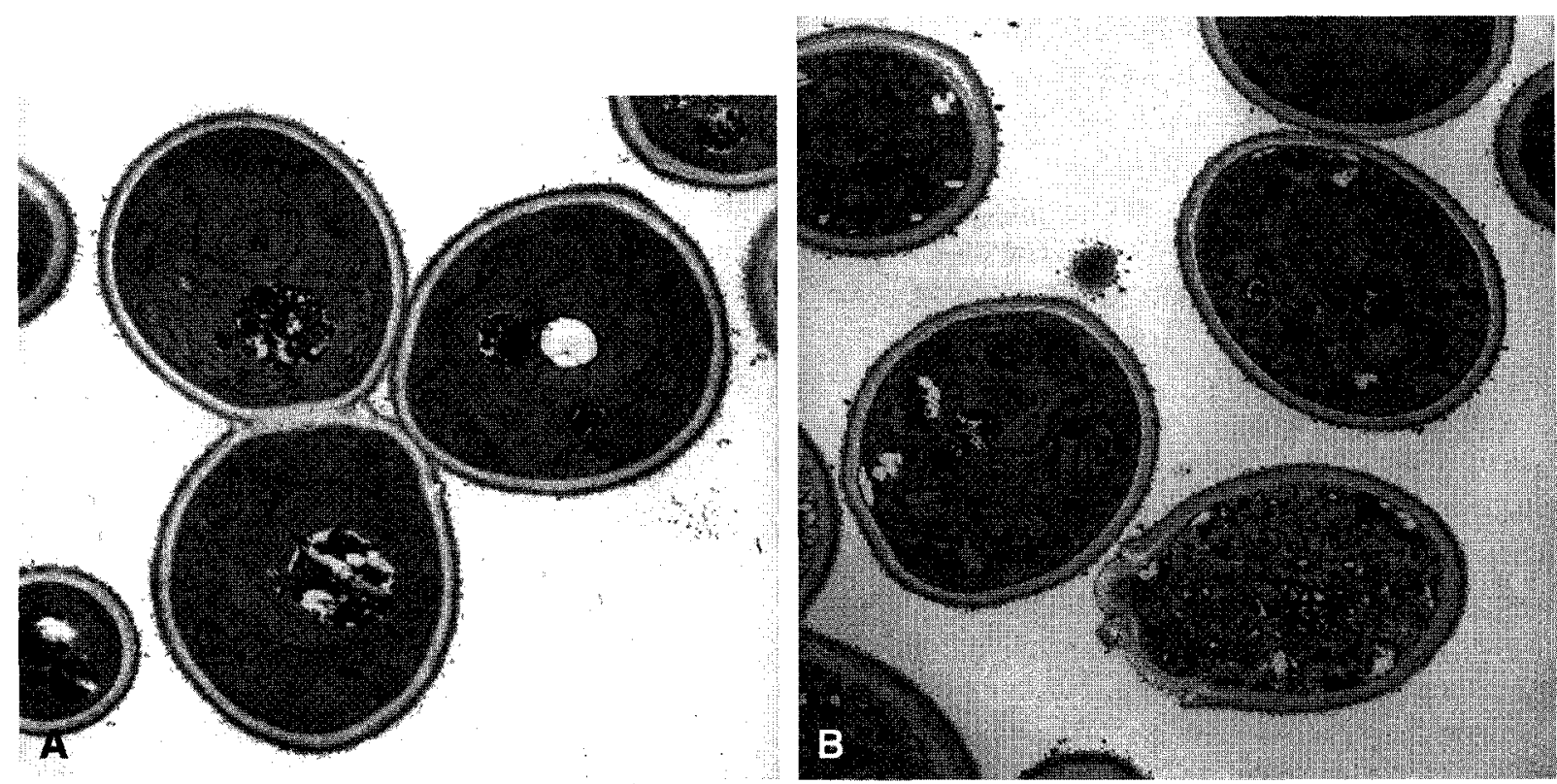

Fig. 5. A. Transmission electron microscopy of untreated C. albicans, ATCC strain 1023I, cells after fixation with glutaraldehyde/permanganate/uranyl. $N$, nucleus; $M$, mitochondria; $R$, endoplasmic reticulum; $V$, vacuole. Section contrasted with uranyl-lead $(\times 13,900)$. B. A Candida cell from the same sample as in Fig. 5 A but treated for 60 min with $0.3 \mathrm{mg} / \mathrm{mL}$ of benzydamine. Notice the severe intracytoplasmic disorganization, including the absence of mitochondria and endoplasmic reticulum. Section contrasted with uranyl-lead. $(\times 13,900)$.

treated for 10 minutes with fungicidal concentrations of the drugs most spheroplasts were lysed (Fig. 6, C, D, and E), showing severely damaged cell membranes with gross fractures or extensive solubilization (Fig. 7, B and C). Ultrastructural images of plasma membrane splitting were seen in some drug-exposed yeast cells (Fig. 7C).

\section{DISCUSSION}

Local anesthetic drugs possess antibacterial and antifungal properties..$^{9,18-22}$ However, their antifungal mechanisms have not yet been elucidated.

Using a combination of complementary methodologies, we found the drugs to have a marked antifungal activity on $C$. albicans that ranged from growth inhibition to complete loss of viability. Growth inhibition can be detected by conventional protocols for MIC determination, as demonstrated in our study. We found that the fungistatic activity of the anesthetics could also be detected, with advantages, by use of FUN-1. Yeast cells exposed to MIC of the drugs showed both inhibition of conversion of the FUN-1 monomer into CIVS and an increase in diffuse intracellular fluorescence, as demonstrated by flow cytometry. These alterations were already detectable after an incubation period of 1 hour, thereby allowing for a more rapid assay as compared with the conventional protocol for MIC determination requiring 24 hours.

The following results point to the mechanism of the fungicidal action of the drugs being due to direct damage to the yeast cytoplasmic membrane. Thus, Candida cells exposed to fungicidal concentrations of the drugs quickly become permeable to the membrane-impermeable fluorochrome PI. This probe has previously been used to evaluate membrane permeability in yeasts and is considered a good marker for cell death associated with membrane alterations. ${ }^{23,24}$ Quantitation of $\mathrm{K}^{+}$leakage from microorganisms, both from bacteria ${ }^{9,25}$ and yeasts. ${ }^{10,26-29}$ has also been used to evaluate membrane damage by various compounds. Yeast cells in the exponential growth phase are known to accumulate $\mathrm{K}^{+}$intracellularly, with concentrations as high as $220 \mathrm{mM} .^{8}$ This cation is quickly lost to the extracellular milieu when the selective membrane permeability is lost. ${ }^{10,26-29} \mathrm{~A}$ very quick and extensive $\mathrm{K}^{+}$leakage was induced by fungicidal concentrations of the local anesthetics, with more than $90 \%$ of the intracellular cation being lost during the initial 10 minutes after exposure to $0.3,50$, or 30 $\mathrm{mg} / \mathrm{mL}$ of benzydamine, lidocaine, or bupivacaine, 

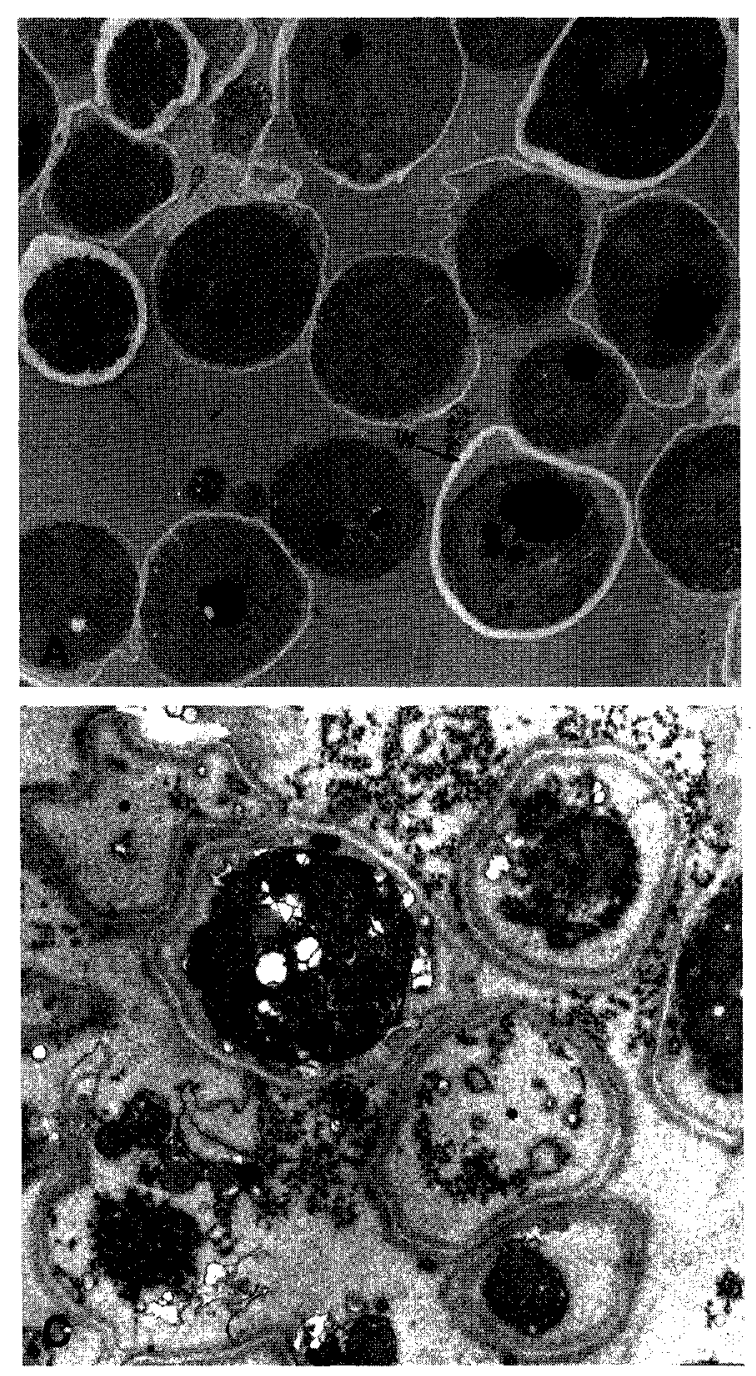

respectively. This indicates that the fungicidal effect results from a direct damage to the cell membrane, rather than from a metabolic impairment leading to secondary membrane damages. In support of this interpretation is our observation that exposure of the Candida cells to fungicidal concentrations of the metabolic inhibitor sodium azide induced $\mathrm{K}^{+}$leakage at a much slower rate as compared to the three local anesthetics. As expected, the membrane-active antimicrobial agent amphotericin $\mathrm{B}$ also induced an extensive and rapid $\mathrm{K}^{+}$ leakage. The extensive loss of intracellular $\mathrm{K}^{+}$may not be the sole factor responsible for the fungicidal activity of the drugs, as the membrane disorganization resulted in multiple perturbations that eventually could be lethal.

Additional support for a direct membrane damaging action of fungicidal concentrations of the anesthetics was evident from the quick lysis of sphe-

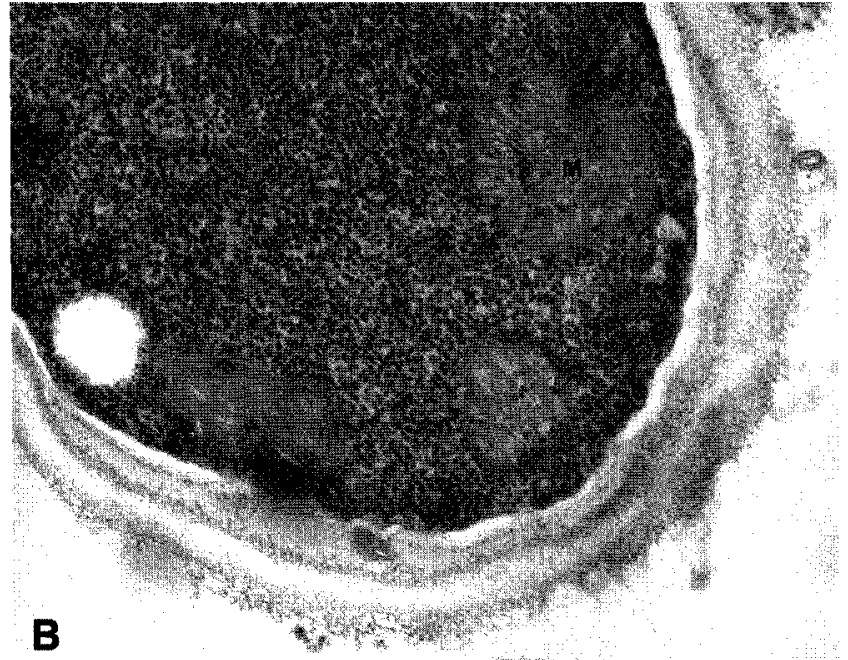

Fig. 6. A. Untreated spheroplasts of $C$. albicans, ATCC strain 10231. Notice the loose partially digested cell walls $(\mathrm{W})$, the intact protoplast with nucleus, mitochondria, and vacuoles. Section stained with uranyl-lead. $(\times 9600)$. B. Spheroplast from the same sample as in Fig. 6A. Section treated with $5 \%$ hydrogen peroxide for 10 minutes followed by lead staining. ${ }^{25}$ Notice the abundant ribosomes in the cytoplasmic matrix and 3 mitochondria $(M) .(\times 50,600)$. C. Spheroplasts from the same preparation as in Fig. 6A but exposed to $0.3 \mathrm{mg} / \mathrm{mL}$ of benzydamine for $15 \mathrm{~min}$. Notice several lysed spheroplasts (*) with collapsed cell walls. The nonlysed spheroplasts have a very altered ultrastructure. Section stained with uranyl-lead. $(\times 16,000)$.

roplasts in an osmotically protective medium, when exposed to fungicidal concentrations of the drugs. Bacterial protoplasts are quickly lysed by treatment with phenethyl alcohol, tetrazolium salts, or local anesthetics, molecules that are known to directly disorganize bacterial cell membranes. ${ }^{9,25}$ 'The ultrastructural studies revealed a second support for the assumption, which was the severe membrane alterations, with fracturing and solubilization, seen after 10 minutes of exposure to fungicidal concentrations of the drugs.

The poor correlation found between the MIC or $\mathrm{LC}_{50}$ of benzydamine and those of lidocaine and bupivacaine suggests that although the drugs kill Candida by acting on a common target (the cell membrane), the mechanisms for the membrane damage would differ in regards to benzydamine on the one hand and lidocaine and bupivacaine on the other. 


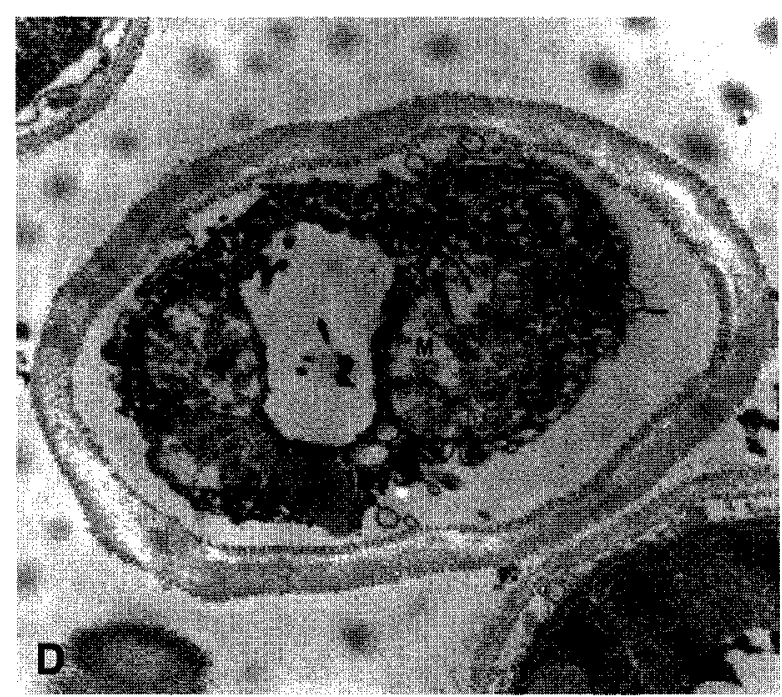

Fig. 6. Continued. D. Spheroplasts from the same preparation as in Fig. 6A but exposed to $30 \mathrm{mg} / \mathrm{mL}$ of lidocaine. Notice the altered ultrastructure of the yeast protoplast, with very distorted and swollen mitochondria $(M)$, as well as absence of ribosomes and nucleus. Cell walls are partially digested. Section stained with uranyl-lead. ( $\times 32,000)$. E. Spheroplasts from the same preparation as in Fig. 6A

The proposed mechanism for the fungicidal activity of the drugs is in conformity with the lipophilic properties of membrane-active molecules due to their lipophilic character. It is therefore expected that the antifungal activity of bupivacaine was higher than that of lidocaine because the former anesthetic is more lipophilic. ${ }^{30}$ The same difference in the activity between the two local anesthetics was also found in a previous study on the inhibition of germ tube formation by $C$. albicans. ${ }^{19,22}$ A good correlation between the lipophilic and antibacterial activity of local anesthetics has also been described. ${ }^{9,18}$ These observations agree with the accepted interpretation that anestheticmembrane interaction is of a hydrophobic character, whereby the anesthetic molecule ultimately penetrates the membrane bilayer and accommodates in its hydrophobic interior. ${ }^{31,32}$ Membrane splitting resulting from insertion of several lipophilic molecules, including the local anesthetic tetracaine, into the hydrophobic core of bacterial membranes was described. ${ }^{33}$ This ultrastructural alteration was seen in the present study in lidocaine-treated Candida plasma membranes (Fig. 7C).

The results showing that the three local anesthetics assayed possess an antifungal activity

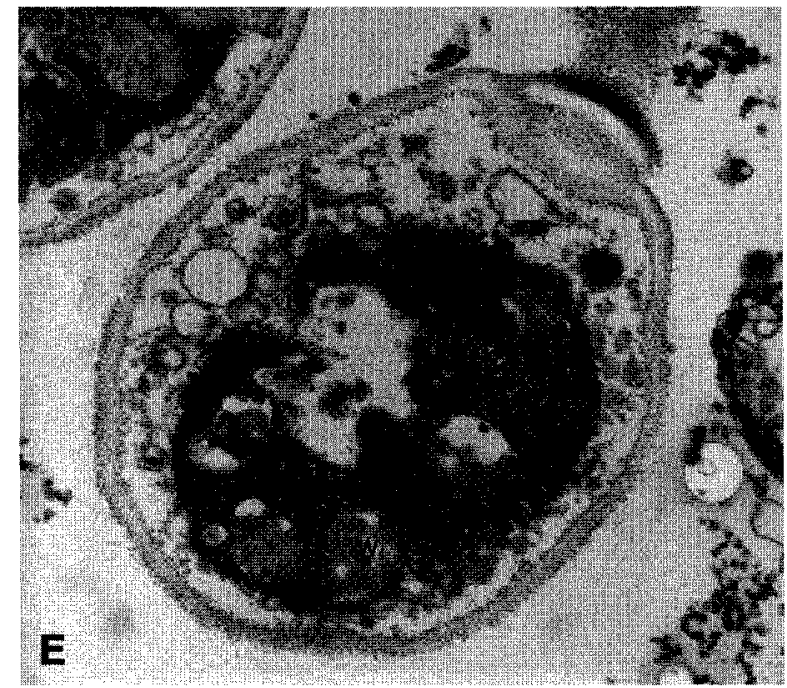

but exposed to $20 \mathrm{mg} / \mathrm{mL}$ of bupivacaine. Notice the altered ultrastructure of the yeast protoplast, with abnormal mitochondria (M), and with absence of ribosomes and nucleus. Cell walls are partially digested. Cellular remnants are present in the much enlarged periplasmic space. Section stained with uranyl-lead. $(\times 35,000)$.

through a membrane-damaging action are in keeping with what has been reported for other lipophilic molecules. This is the case, among others, with amphotericin B, ${ }^{10}$ lipophilic azoles, ${ }^{34}$ butenafine,,${ }^{35}$ and phenothiazines. ${ }^{36,37}$

The observed good correlation coefficients between the MIC (indicator of fungistatic activity) and $\mathrm{LC}_{50}$ (indicating a fungicidal activity) of each of the drugs for the 12 Candida strains tested would suggest that the mechanisms for the fungistatic and fungicidal activities of the drugs are similar, the plasma membrane being a common target. However, when exposing yeast cells to the fungistatic concentrations of the three drugs, no indication of membrane damage was found, since there was no permeability to PI nor production of $\mathrm{K}^{+}$leakage. This may be explained by the short incubation time (10 minutes) used in the incubations prior to the above two membrane integrity tests.

The present results show that the three drugs now studied could be used topically to treat mucosal or cutaneous candidosis because concentrations with antifungal activity can be obtained with the commercial formulations available, mainly with benzydamine, the most active of the three drugs we tested. In fact, benzydamine is available in gels with $3 \%$ and $5 \%$ of the drug, ${ }^{38}$ and these concen- 

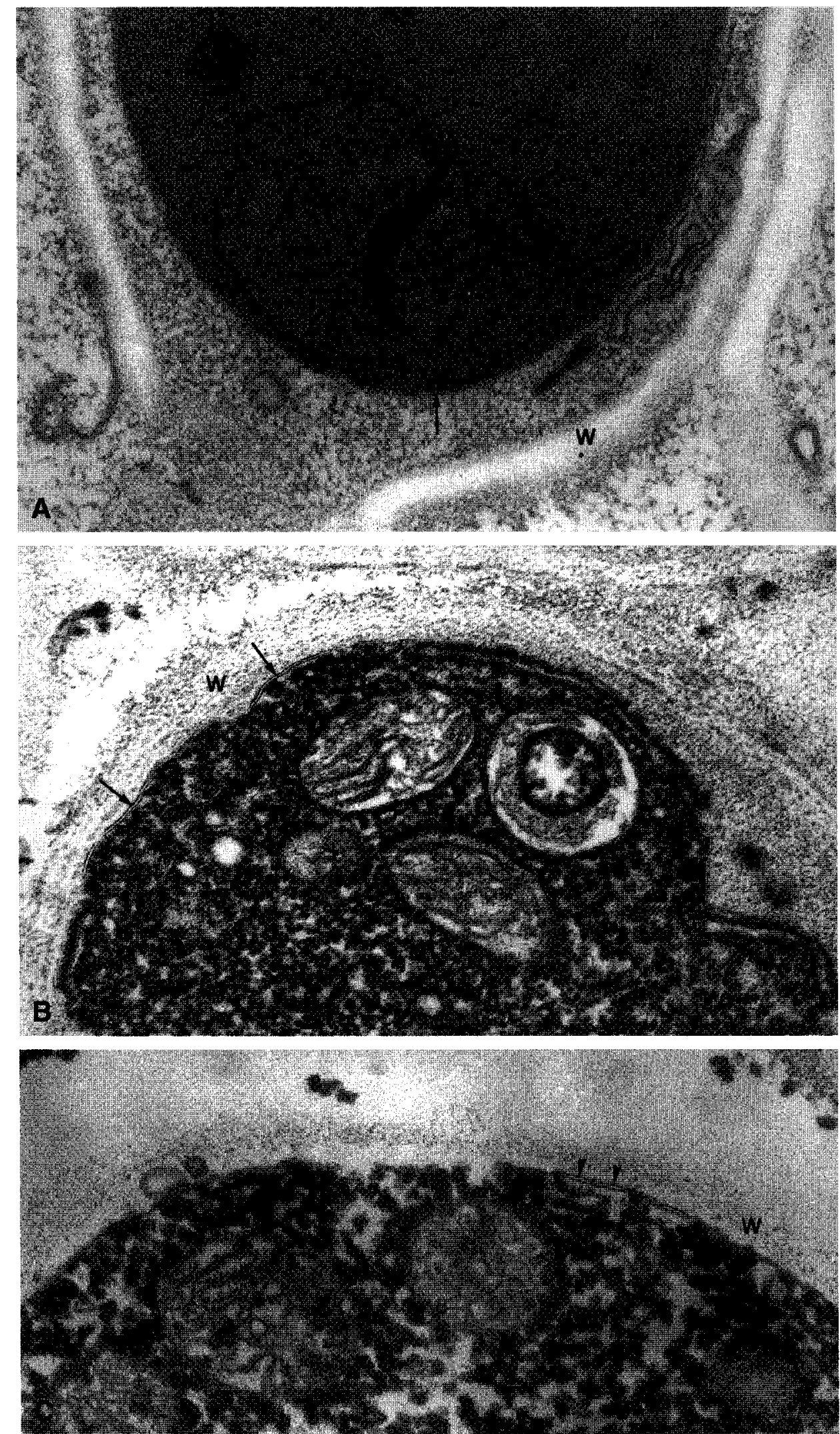

Fig. 7. A. High magnification of a spheroplast of control cells showing the continuous, triple-layered cytoplasmic membrane (arrow). W, partially digested cell wall. Section stained with uranyl-lead. $(\times 72,000)$. B and C. Same conditions as in Fig. 7A but the spheroplast had been exposed to $0.3 \mathrm{mg} / \mathrm{mL}$ of benzydamine (B) or $30 \mathrm{mg} / \mathrm{mL}$ of lidocaine (C) for $15 \mathrm{~min}$. Notice the extensive solubilization of the cytoplasmic membrane, with only small remnants left (arrows). In $\mathrm{C}$, the membrane remnants show zones with increased membrane thickness, indicating membrane splitting (arrow heads). W, partially digested cell wall. Sections stained with uranyl-lead. $(\times 72,000)$. 
trations are 600 and 1000 times higher, respectively, than the MIC for the least susceptible Candida strain we studied. Benzydamine solutions for oral and vaginal applications contain $0.15 \%,{ }^{38}$ a concentration that is 30 times higher than the MIC of the least susceptible Candida strain. Commercial formulations of lidocaine and bupivacaine contain drug concentrations ${ }^{38}$ that are up to 40 times above the MIC of most strains we studied. It should be emphasized, additionally, that the analgesic properties of the three drugs we studied represent an additional advantage for their topical use in the management of Candida infections.

\section{ACKNOWLEDGEMENTS}

We thank Manuel T. Silva for helpful support, Cecília Leão and Manuela Côrte-Real for reviewing the manuscript, and Clara Coelho, Alexandre Salvador, and Paula M. Macedo for excellent technical assistance.

\section{REFERENCES}

1. Sobel JD. Epidemiology and pathogenesis of recurrent vulvovaginal candidiasis. Am J Obstet Gynecol 1985; 152:924-935.

2. Martinez-de-Oliveira J, Silva-Cruz A, Freitas-daFonseca A, et al: Prevalence of Candida albicans in the vaginal fluid of Portuguese women. J Reprod Med 1993; $38: 41-42$.

3. Stevens DA. Problems in antifungal chemotherapy. Infection 1987;15:87-92.

4. Boken DJ, Swidells S, Rinaldi MG. Fluconazoleresistant Candida albicans. Clin Infect Dis 1993;17:10181021.

5. Denning DW. Can we prevent azole resistance in fungi? Lancet 1995;346:454-455.

6. Cederlund H, Mårdh PA. Antibacterial activities of nonantibiotic drugs. J Antimicrob Chemother 1993;32:355365.

7. National Committee for Clinical Laboratory Standards. Reference method for broth dilution antifungal susceptibility testing of yeasts. Approved standard M27-A. Wayne, PA: National Committee for Clinical Laboratory Standards, 1997.

8. Jones WB, Rothestein A, Sherman F, Stannard JN. Variation of $\mathrm{K}^{+}$and $\mathrm{Na}^{+}$content during the growth cycle of yeast. Biochim Biophys Acta 1965;104:310-312.

9. Silva MT, Sousa JCF, Polónia JJ, Macedo MAE. Effects of local anesthetics on bacterial cells. J Bacteriol 1979; 137:461-468.

10. Beggs WH. Physicochemical cell damage in relation to lethal amphotericin B action. Antimicrob Agents Chemother 1994;38:363-364.

11. Millard PJ, Roth BL, Thi H-P'T, et al. Development of the FUN-1 family of fluorescent probes for vacuole la- beling and viability testing of yeasts. Appl Environ Microbiol 1997;163:2897-2905.

12. Prudêncio C, Sansonetty F, Côrte-Real M. Flow cytometric assessment of cell structural and functional changes induced by acetic acid in the yeasts Zygosaccharomyces bailii and Saccharomyces cerevisiae. Cytometry 1998;31:307-313.

13. Adams CC, Gross DS. The yeast shock response is induced by conversion of cells to spheroplasts and by potent transcriptional inhibitors. J Bacteriol 1991;173: $7429-7435$.

14. Numata K, Ueki T, Naito N, et al. Morphological changes of Candida albicans induced by BMY-28864, a highly water-soluble pradimicin derivative. J Electron Microscop 1993;42:147-55.

15. Silva MT, Santos-Mota JM, Melo JVC, Carvalho-Guerra F. Uranyl salts as fixatives for electron microscopy. Study of membrane ultrastructure and phospholipid loss in bacilli. Biochim Biophys Acta 1971;233:513-520.

16. Silva MT, Appelberg R, Silva MNT, Macedo PM. In vivo killing and degradation of Mycobacterium aurum within mouse peritoneal macrophages. Infect Immun 1987;55:2006-2016.

17. Silva M'T. Electron microscopic study on the effect of the oxidation of ultrathin sections of Bacillus cereus and Bacillus megaterium. J Ultrastruct Res 1967;18:345-353.

18. Collura V, Letellier L. Mechanism of penetration and of action of local anesthetics in Escherichia coli cells. Biochim Biophys Acta 1990;1027:238-244.

19. Rodrigues A, Pina-Vaz C, Fonseca AF, et al. In vitro effect of local anesthetics on Candida albicans germ tube formation. Infect Dis Obst Gynecol 1994;1:193-197.

20. Mullin GS, Rubinfeld RS. The antibacterial activity of topical anesthetics. Cornea 1997;16:662-665.

21. Bátai I, Kerenyi $M$, Tekeres $M$. The impact of drugs used in anesthesia on bacteria. Eur J Anesth 1999;16: $425-440$.

22. Rodrigues A, Pina-Vaz C, Mårdh PA, et al. Inhibition of germ tube formation by Candida albicans by local anesthetics: an effect related to ionic channel blockade. Curr Microbiol 2000;40:145-148.

23. Shapiro HM. Practical flow cytometry. 2nd ed. New York: Alan R. Liss Press, 1988.

24. Pore S. Antibiotic susceptibility testing of Candida albicans by flow cytometry. Curr Microbiol 1990;20:323 328.

25. Silva MT, Sousa JCF, Macedo MAE, et al. Effects of phenethyl alcohol on Bacillus and Streptococcus. J Bacteriol 1976;127:1359-1369.

26. Gale EF. The release of potassium ions from Candida albicans in the presence of polyene antibiotics. J Gen Microbiol 1974;80:451-465.

27. Bussey H, Skipper N. Membrane-mediated killing of Saccharomyces cerevisiae by glycoproteins from Torulopsis glabrata. J Bacteriol 1975;124:476-483.

28. Eilam Y, Grossowicz N. Nystatin effects on cellular calcium in Saccharomyces cerevisiae. Biochim Biophys Acta 1982;692:238-243.

29. Midez JA, Hopfer RL, Lopez-Berestein G, Mehta RT. 
Effects of free and liposomal amphotericin B and gramicidin $S$ alone and in combination on potassium leakage from human erythocytes and Candida albicans. Antimicrob Agents Chemother 1989;33:152-155.

30. Nietgen GW, Chan CK, Durieux ME. Inhibition of lysophosphatidate signaling by lidocaine and bupivacaine. Anesthesiology 1997;86:1112-1119.

31. Papahadjopoulos D. Studies on the mechanism of action of local anesthetics with phospholipid model membranes. Biochim Biophys Acta 1972;265:169-186.

32. Seeman $P$. The membrane actions of anesthetics and tranquilizers. Pharmacol Rev 1972;24:583-655.

33. Silva MT, Polónia JJ, Macedo MAE, Macedo PM. Membrane splitting induced by lipophilic molecules. Biol Cell 1979;35:175-182.
34. Sud IJ, Feingold DS. Heterogeneity of action mechanisms among antimycotic imidazoles. Antimicrob Agents Chemother 1981;20:71-74.

35. Iwatani W, Arika T, Yamaguchi H. Two mechanisms of butenafine action on Candida albicans. Antimicrob Agents Chemother 1993;37:785-788.

36. Wood NC, Nugent KM. Inhibitory effects of chloropromazine on Candida species. Antimicrob Agents Chemother 1985;27:692-694.

37. Eilam Y, Polacheck I, Ben-Gigi G, Chernichovsky D. Activity of phenothiazines against medically important yeasts. Antimicrob Agents Chemother 1987;31:834-836.

38. Parfitt K (ed). Martindale: The extra pharmacopeia. London: Pharmaceutical Press, 1999. 


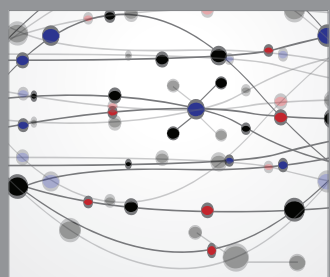

The Scientific World Journal
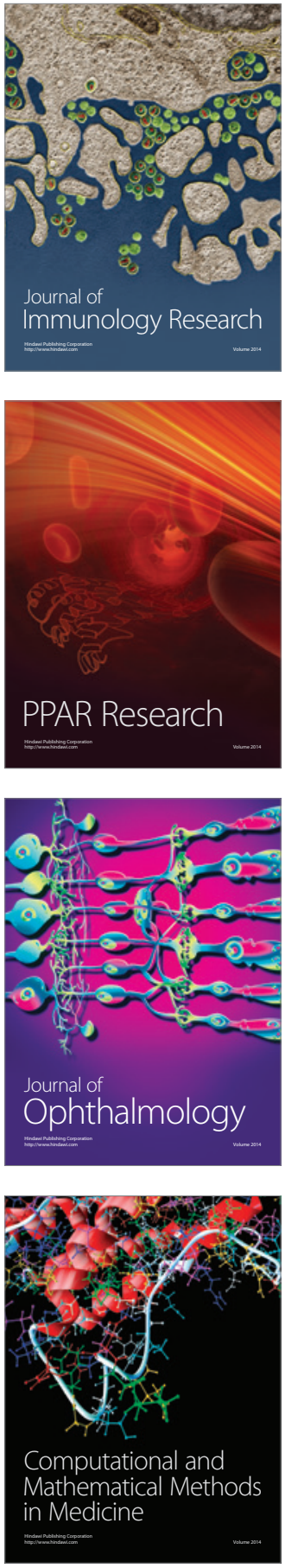

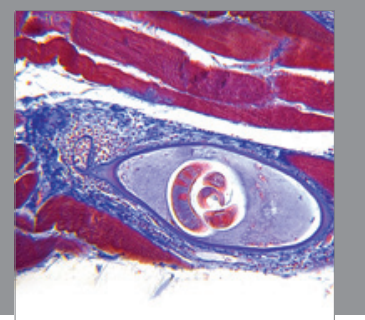

Gastroenterology

Research and Practice
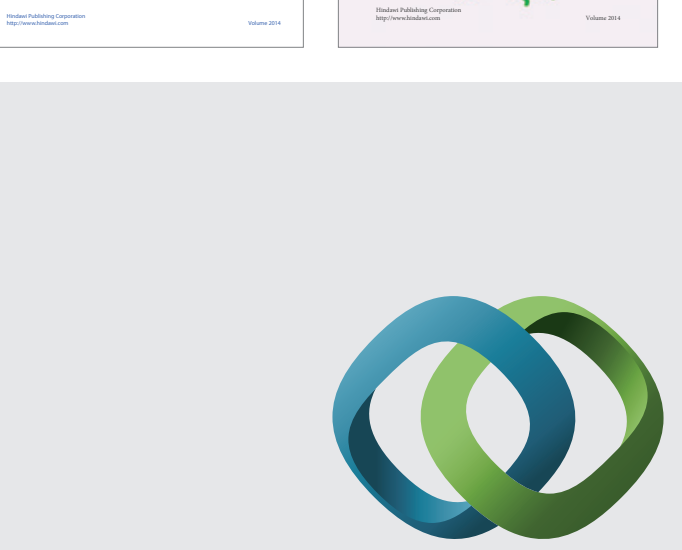

\section{Hindawi}

Submit your manuscripts at

http://www.hindawi.com
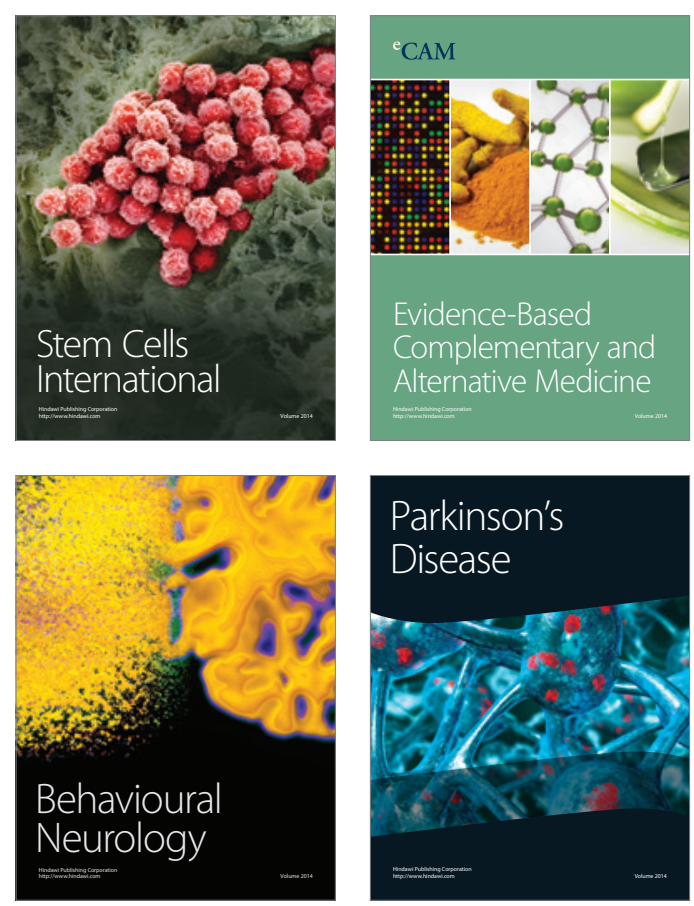

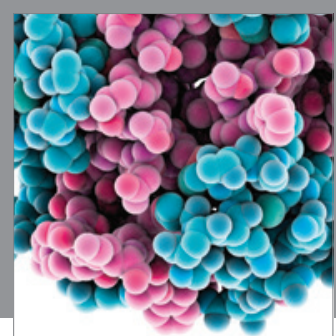

Journal of
Diabetes Research

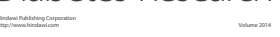

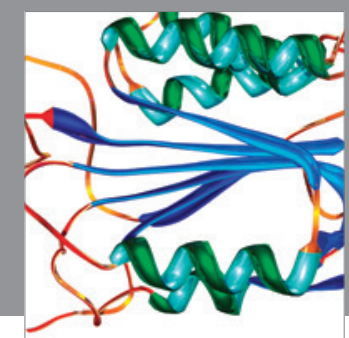

Disease Markers
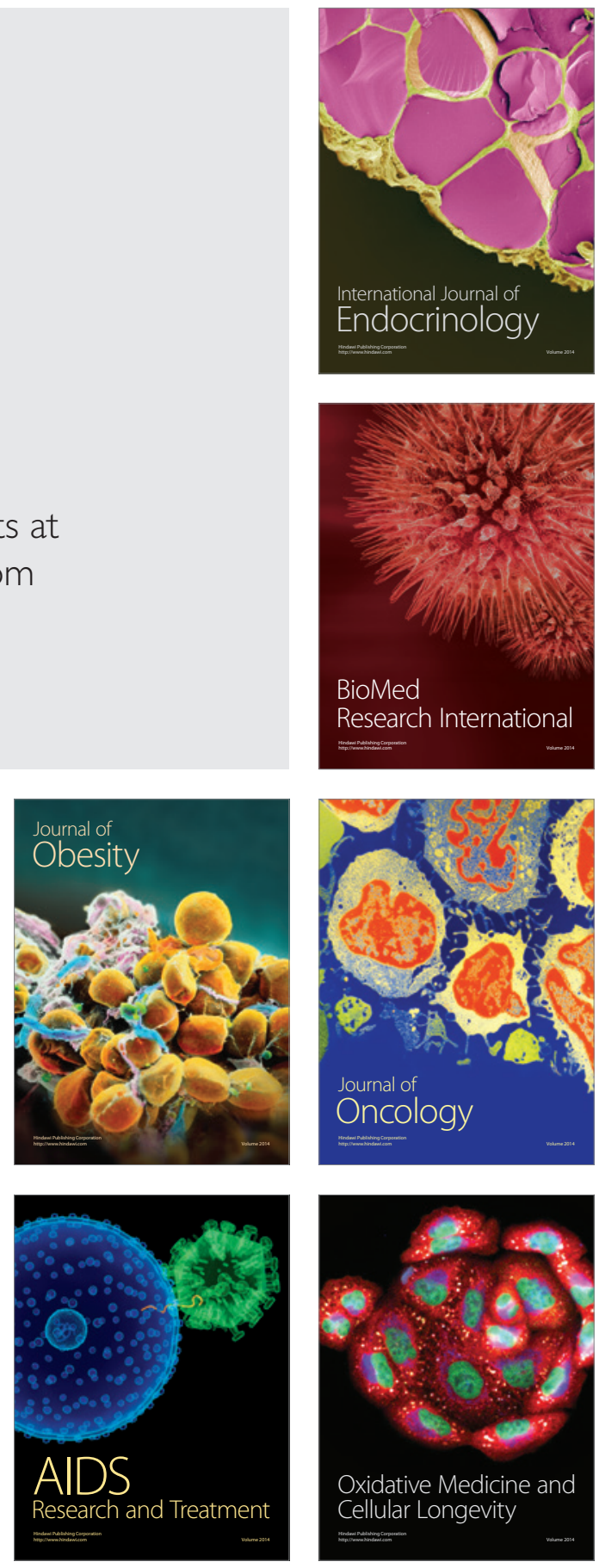